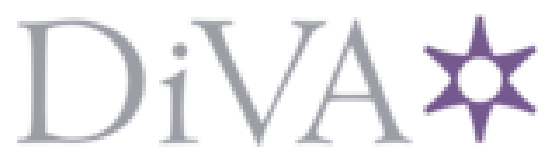

http://www.diva-portal.org

\title{
Preprint
}

This is the submitted version of a paper published in Free radical research.

Citation for the original published paper (version of record):

Anvari, E., Wikström, P., Walum, E., Welsh, N. (2015)

The novel NADPH oxidase 4 inhibitor GLX351322 counteracts glucose intolerance in high-fat diet-treated C57BL/ 6 mice..

Free radical research, $49(11)$

http://dx.doi.org/10.3109/10715762.2015.1067697

Access to the published version may require subscription.

N.B. When citing this work, cite the original published paper.

Permanent link to this version:

http://urn.kb.se/resolve?urn=urn:nbn:se:uu:diva-273312 


\section{The novel NADPH oxidase 4 inhibitor GLX351322 counteracts glucose intolerance in high-fat diet-treated C57BL/6 mice}

Ebrahim Anvari¹, Per Wikström², Erik Walum², Nils Welsh ${ }^{1}$

${ }^{1}$ Science for Life Laboratory, Department of Medical Cell Biology, Uppsala University, Box 571, SE-751 23 Uppsala, Sweden.

${ }^{2}$ Glucox Biotech AB, Hallandsgatan 28, SE-118 57 Stockholm, Sweden

Abbreviated title: NOX inhibitor protects against glucose intolerance

Key words: NOX inhibitor, human islet, reactive oxygen radical, NADPH oxidase, insulin release, beta-cell death, glucose intolerance

Corresponding author:

Nils Welsh, Science for Life Laboratory, Department of Medical Cell Biology, Box 571, BMC, SE-751 23 Uppsala, Sweden. Phone: +46 184714212

E-mail: nils.welsh@mcb.uu.se

Author Contributions:

EA and PW performed the experiments. PW, EW and NW designed the experiments, analyzed the results and wrote the manuscript. 


\section{ABSTRACT}

In Type 2 diabetes, it has been proposed that pancreatic beta-cell dysfunction is promoted by oxidative stress caused by NADPH oxidase (NOX) over-activity. Five different NOX enzymes (NOX1-5) have been characterized, among which NOX1 and NOX2 have been proposed to negatively affect beta-cells, but the putative role of NOX4 in type 2 diabetes-associated beta-cell dysfunction and glucose intolerance is largely unknown. Therefore, we presently investigated the importance of NOX4 for high-fat diet (HFD)-induced glucose intolerance using male C57BL/6 mice using the new NOX4 inhibitor GLX351322, which has relative NOX4 selectivity over NOX2. In HFD-treated male C57BL/6 mice a two-week treatment with GLX351322 counteracted non-fasting hyperglycemia and impaired glucose tolerance. This effect occurred without any change in peripheral insulin sensitivity. To ascertain that NOX4 also plays a role for the function of human beta-cells, we observed that glucose- and sodium palmitate-induced insulin release from human islets in vitro was increased in response to NOX4 inhibitors. In longterm experiments (1-3 days), high glucose-induced human islet cell ROS production and death were prevented by GLX351322. We propose that whilst short-term NOX4generated ROS production is a physiological requirement for beta-cell function, persistent NOX4-activity, e.g. during conditions of high-fat feeding, promotes ROSmediated beta-cell dysfunction. Thus, selective NOX-inhibition may be a therapeutic strategy in Type 2 diabetes. 


\section{INTRODUCTION}

Loss of pancreatic islet function is a central hallmark in the pathogenesis of Type 2 diabetes mellitus (T2DM) [1]. In addition, it may be that also beta-cell loss occurs in T2DM, and that this starts, after an initial phase of hyperinsulinemia, relatively late in the progression of the disease [2]. The mechanisms resulting in beta cell failure in T2DM are not clear, but accumulating evidence point to a central role of oxidative stress as a result of overproduction of reactive oxygen species (ROS) [3-6]. Chronic hyperglycemia/hyperlipidemia may be the driving force that leads to increased ROS production, and ROS are known to damage components of the cellular machinery, including DNA, proteins and lipids. Besides damaging islet cells, it is likely that oxidative stress is contributing to the development of peripheral insulin resistance, and to many of the vascular complications occurring in the late stages of the disease [7-11].

The excessive production and accumulation of ROS is, at least in part, due to hyperactivity of the NADPH oxidases (NOX). The NOX family consists of seven isoforms (NOX1-5 and DUOX1-2), which perform normal cellular functions at basal conditions, but when persistently activated produce harmful levels of ROS. Hyperactivity of some of the isoforms has been found to be an important driver in a number of diseases including diabetes and diabetes complications [12]. Both rat and human pancreatic beta-cells have been reported to express some of the NOX subunits [13-15], and NOX2 seems to be activated in response to glucose stimulation through a protein kinase C-dependent mechanism [13], leading to an increased intracellular calcium response and a stimulated insulin release [16-18]. However, in vivo studies have reported increased NOX-mediated ROS generation in diabetic rat and human islets, and that this was associated with reduced beta-cell function [19]. Thus, it may be that insulin release is stimulated in the 
short term by increased ROS production, whereas a long-term NOX-activation leads to loss of beta-cell function. Not only glucose in vitro or hyperglycemia in vivo promotes beta-cell activation of NOX, but also sodium palmitate, a free fatty acid which is increased in Type 2 diabetes, and which stimulates the release of insulin in short-term experiments, but inhibits beta-cell function after a prolonged exposure period [20-22]. Activation of NOX in islet non-beta-cells may also contribute to ROS production and oxidative stress in the beta-cells. In this instance NOX activation in endothelial cells could be of importance. Patel et al [23] highlighted a unique framework for hyperglycemia-induced hydrogen peroxide production by NOX in endothelial cells and Hecker et al [24] found that an aberrant up-regulation of the isoenzyme NOX4 results in a sustained redox imbalance, which promotes persistent myofibroblast senescence and fibrosis. In this context it is of interest to note that pancreatic islets are among the most vascularized organs in the body with 1000-1500 capillaries per square millimeter, i.e. encompassing $10 \%$ of the islet tissue [25].

In previous studies NOX2 and NOX1 have been suggested to negatively affect beta-cell function when persistently over-activated $[19,26]$. The putative role of NOX4 in isletcells, however, has not been addressed. Previously used NOX inhibitors, such as apocynin and diphenylene iodonium, are today not considered to be selective NOX inhibitors. Instead, novel NOX inhibitors with better NOX specificity, and which are selective for specific NOX isoforms, have been developed [27]. One such NOX inhibitor is GKT-136901, which inhibits NOX1 and NOX4 more efficiently than NOX2, and which counteracts high glucose-induced oxidative stress in the kidney [28]. We presently report the generation of a new NOX inhibitor, GLX351322, which targets NOX4 preferentially over NOX2. The aim of the present investigation was to evaluate whether GLX351322 counteracts high-fat diet-induced hyperglycemia and glucose intolerance in 
C57BL/6 mice. Using this NOX4 inhibitor we observed protection against beta-cell dysfunction, suggesting that a long-term NOX4-mediated stimulation of islet ROS production contributes to subsequent beta-cell failure and glucose intolerance.

\section{METHODS}

\section{NOX inhibitors}

2-(2-chlorophenyl)-4-methyl-5-(pyridin-2-ylmethyl)-1H-pyrazolo[4,3-c]pyridine3,6(2H,5H)-dione (GKT-136901), a selective NOX4 inhibitor, was a kind gift from Dr. Harald HH Schmidt [Maastricht University, Netherlands]. GLX351322 (ethyl 2-[[2-[4(furan-2-carbonyl)piperazin-1-yl]acetyl]amino]-5,6-dihydro-4H-cyclopenta-

[b]thiophene-3-carboxylate) was a kind gift from Glucox Biotech (Stockholm, Sweden). Diphenylene iodonium (DPI) was from Sigma Aldrich.

\section{Identification of GLX351322 as a NOX4 inhibitor}

Using a high throughput screening approach 40.000 chemicals were tested for NOX4 inhibition potential in T-REx-293 cells with inducible NOX4 over-expression using an Amplex red based assay in a 384-well format. With $50 \%$ inhibition of NOX4 as threshold, more than 700 primary hits were identified. These were re-tested using the

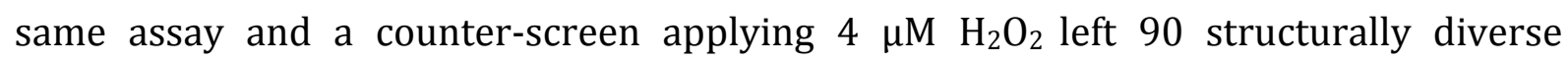
compounds for dose-response investigation. Dose-response curves were obtained from $200 \mu \mathrm{M}$ in 113 -fold-dilution steps in duplicate and 54 compounds received an $\mathrm{IC}_{50}$. The most potent compounds had an $\mathrm{IC}_{50}$ of approximately $1 \mu \mathrm{M}$. None of the compounds showed any effect on cell viability at $10 \mu \mathrm{M}$. 
To exclude any form of general antioxidant activity of GLX351332 the DPPH assay was utilized. DPPH (2,2-diphenyl-1-picryl-hydrazyls-hydrate) is a well-known stable radical useful to determine all types of chemical reactions involving radicals [29]. A strong absorption band centered at $518 \mathrm{~nm}$ (violet color) decreases to pale yellow when the DPPH radical is neutralized by an antioxidant. DPPH (Sigma Aldrich) absorbance at 518 nm was determined without or in the presence of different GLX531322 concentrations. As positive control GLX481369, a substance with known redox activity, was used. The assay was performed in 96 wells plates and absorbance was determined in a plate reader.

\section{Determination of GLX351322 IC $_{50}$ for inhibition of NOX2}

On the basis of the high throughput screen campaign results and a first analysis of doseresponse curves 12 compounds were selected and tested for selectivity against NOX2. Assay procedures are described in Wilcke et al [30]. Erythrocytes were isolated from whole blood by Dextran sedimentation and kryopreserved according to [31]. Before assaying, cells were thawed at $37^{\circ} \mathrm{C}$ and immediately pipetted into room tempered Hank's balanced salt solution (HBSS) and centrifuged (250 x g, $\left.5 \mathrm{~min}, 20^{\circ} \mathrm{C}\right)$. Cells were washed twice in HBSS and re-suspended in HBSS at $2 \times 10^{6}$ cells $/ \mathrm{ml}$. Cell count and viability was determined using Trypan Blue exclusion. One vial per assay plate was used, thawed and prepared just prior to analysis. Phorbol 12-myristate 13-acetate (PMA) was diluted in Isoluminol buffer at $4 \mathrm{x}$ working concentration to a final concentration of 30 ng/ml. Cells were stimulated with PMA to produce radicals from NOX2 enzyme.

\section{Determination of GLX351322 solubility}

Solubility of GLX351322 was tested utilizing the shake-flask method in three different 
media, $0.1 \mathrm{M}$ phosphate buffer $\mathrm{pH}$ 7.4, FASSIF (synthetic fluid representing small intestinal juices when no food has been ingested) blank pH 6.5 (without lipids) and FASSIF pH 6.5. In brief, approximately $0.5 \mathrm{mg}$ GLX351322 was weighed in HPLC glass vials. $0.5 \mathrm{ml}$ of either media described above was added, the vials was sealed and incubated with rotation (900 rpm) at $37^{\circ} \mathrm{C}$ for $24 \mathrm{~h}$. After the incubation, an aliquot was centrifuged at $10000 \mathrm{rpm}$ (to remove in insoluble matter) and the supernatant was diluted and analyzed by LC-MS/MS.

\section{Determination of GLX351322 chemical stability}

GLX351322 (1 $\mu$ M from a $10 \mathrm{mM}$ DMSO stock) was incubated in closed glass vials at $37^{\circ} \mathrm{C}$ in phosphate buffered saline (PBS) at pH 7 and in PBS:Propanol (1:1) at the same $\mathrm{pH}$ for $24 \mathrm{~h}$. Aliquots of the buffer stock solutions were immediately frozen at $-80^{\circ} \mathrm{C}$ after incubation. After thawing, the samples were analyzed by LC-MS/MS and compared to control samples.

\section{Determination of GLX351322 metabolic stability}

The microsomal metabolic stability assay utilized commercially available pooled human liver microsomes with supplemented cofactor (NADPH) to primarily facilitate cytochrome P450 reactivity against target compound. GLX351322 (1 $\mu \mathrm{M})$ and microsomes $(0.5 \mathrm{mg} / \mathrm{ml}$ incubation concentration) are added to $150 \mathrm{ml}$ of $0.1 \mathrm{M}$ phosphate buffer $\mathrm{pH}$ 7.4. The reaction is initiated with addition of NADPH (1 mM). The incubation times were $0,5,15,40 \mathrm{~min}$ and the reaction was quenched, at each time point, by addition of $100 \mu \mathrm{l}$ acetonitrile containing Warfarin as analytical internal standard. The plate was then sealed, centrifuged and frozen at $-20^{\circ} \mathrm{C}$ until LC-MS/MS analysis. 


\section{Determination of GLX351322 plasma protein binding}

In brief, $0.2 \mathrm{ml}$ of the plasma test solution (typically $10 \mu \mathrm{M}$ final compound concentration) was transferred to the membrane tube in the RED (Rapid Equilibrium Dialysis) insert. $0.35 \mathrm{ml}$ isotonic phosphate buffer $\mathrm{pH} 7.4$ was added to the other side of the membrane. The sample was incubated with rapid rotation $(900 \mathrm{rpm})$ at $37^{\circ} \mathrm{C}$ for $4 \mathrm{~h}$ to achieve equilibrium. The plasma test solution was incubated at $37^{\circ} \mathrm{C}$ for $4 \mathrm{~h}$ and then frozen to prevent any degradation. Prior to LC-MS/MS analysis the samples were mixed with equal volumes of control buffer or plasma as appropriate to maintain matrix similarity for analysis. Plasma proteins were then precipitated by the addition of methanol (1:4) containing Warfarin as analytical internal standard. The plate is then sealed, centrifuged and the supernatant is analyzed by mass spectrometry (LC-MS/MS).

\section{Determination of GLX351322 transport}

Caco-2 cell permeability study was performed in accordance with published protocols [32]. The experiment was started by applying a prewarmed $\left(37^{\circ} \mathrm{C}\right)$ GLX351322 solution of $1 \mu \mathrm{M}$ on the apical side of the filter insert chamber. Directly after the termination of the experiment the membrane integrity was checked by transepithelial electrical resistance (TEER) measurement and by measurement of mannitol permeability.

\section{Determination of oral pharmacokinetics in rat}

Sprague Dawley rats (males, 8-12 weeks) were acquired from Harlan Europe. The animals were weighed day 1 and mean weight was calculated for determination of dose for the experiment. $3 \times 3$ rats per group were used and animals were dosed p.o. with 10 mg of GLX351322 per kg. Plasma samples were taken at 0 time and after $10 \mathrm{~min}, 30 \mathrm{~min}$, 
1 h, 1,5 h, 2 h, 3 h, 4 h, 6 h, 8 h, 18 h, 24 h, 48 h, and 72 h. The samples were analyzed by UPLC-MS/MS. Data was processed and analyzed using MassLynx (Walters Corp.), Graphpad Prism 4 (Graphpad Inc.) and WinNonlin (Pharsight Corp.).

The animal experiment was approved by the local ethical committee Malmö/Lund; license M152-09.

\section{Human Islets}

Human pancreatic islets were kindly provided by Prof. Olle Korsgren (Dept. of Radiology, Oncology and Clinical Immunology, Uppsala University Hospital, Uppsala, Sweden), through the Uppsala facility for the isolation of human islets from Scandinavian brain-dead individuals. After isolation, the islets were cultured freefloating in Sterilin dishes in CMRL 1066 medium (ICN Biomedicals, Costa Mesa, CA, USA) containing $5.6 \mathrm{mM}$ glucose, $10 \%$ fetal calf serum and $2 \mathrm{mM}$ L-glutamine for 1-5 days. All cells were kept at $37^{\circ} \mathrm{C}$ in a humidified atmosphere with $5 \% \mathrm{CO}_{2}$.

\section{Insulin release}

Islets were incubated for $1 \mathrm{~h}$ in either $1.7 \mathrm{mM}$ glucose, $17 \mathrm{mM}$ glucose or $17 \mathrm{mM}$ glucose +1 $\mathrm{mM}$ sodium palmitate solubilized in $2 \%$ bovine serum albumin at $37^{\circ} \mathrm{C}$ and in HEPESbalanced Krebs-Ringer bicarbonate buffer (KRBH) buffer. Insulin concentrations were measured using an Insulin ELISA Kit (Mercodia).

\section{ROS production in human islets}

After a 24 h culture period in 5.6 or $28 \mathrm{mM}$ glucose, human islets were loaded for $60 \mathrm{~min}$ at room temperature with the free radical indicator carboxy- $\mathrm{H}_{2}$ DCFDA (5-(and-6)carboxy-2',7'-dichlorodihydrofluorescein diacetate, $10 \mu \mathrm{M}$, Life Technologies, 
Stockholm, Sweden). Thereafter the cells were transferred to culture dishes containing 5.6 or $28 \mathrm{mM}$ glucose with or without $10 \mu \mathrm{M}$ GLX531322 and $10 \mu \mathrm{M}$ DPI, and incubated for another $60 \mathrm{~min}$ at $37^{\circ} \mathrm{C}$. Hoechst stain, which labels cell nuclei, was added during the last 20 of this incubation. The islets were then washed and placed on the stage of an inverted confocal microscope (Nikon C1) and analyzed for green (DCF) and blue fluorescence (Hoechst). Intensities were determined using Adobe Photoshop and ratios between green and blue signals were calculated as a relative measure of oxidative stress.

\section{Evaluation of cell viability}

The cell viability of human islet cells was assessed after culture with IL-1 $\beta$ (20 ng/ml) + IFN$\gamma(20 \mathrm{ng} / \mathrm{ml})$ or with $20 \mathrm{mM}$ glucose for three days. Cell viability was measured by staining cells with propidium iodide $(20 \mu \mathrm{g} / \mathrm{ml})$ and bisbenzimide $(5 \mu \mathrm{g} / \mathrm{ml})$ for $20 \mathrm{~min}$ at $37^{\circ} \mathrm{C}$. The medium was replaced with PBS and the red and blue fluorescence was detected using the Kodak $4000 \mathrm{MM}$ image station. The ratio of red to blue was taken as a relative measure of cell death (necrosis and late apoptosis) and was quantified using Carestream MI Digital Science ID software, version 5.0.6.20.

\section{Animals and high-fat diet treatment}

Four weeks old male C57Bl/6J mice were purchased from Scanbur AB (Sollentuna, Sweden). When five weeks of age mice were divided into two groups with 20 mice in each: one given a control diet (CD) and one given a high-fat diet (HFD). The high-fat diet (D12492, Research Diets) contained $60 \mathrm{kcal} \%$ fat, whereas the normal diet (D12450B, Research Diets) contained only 10\% kcal\% fat. After 7 weeks of diet, both groups were randomly divided into two subgroups, one receiving GLX351322 (3.8 mg/day/kg body 
weight) in the drinking water and one group receiving no supplementation. The amount of GLX351322 in the drinking water was continuously adjusted according to water intake and body weight of the four groups. To determine the blood glucose concentrations, blood was withdrawn from the tip of the tail and analyzed using the Freestyle Mini System. The same person collected all blood samples for blood glucose determinations. The animal experiments were approved by the local animal ethics committee.

\section{Blood glucose tolerance test}

The mice, after having fasted for approximately 8 hours, were given a single dose of 2.5 g/kg body weight of $30 \% \mathrm{w} / \mathrm{v}$ D-glucose intravenously. Blood was withdrawn from the tail, $\sim 1 \mu \mathrm{l}$, and measured with Freestyle Mini System (Abbot, TheraSense Inc). Blood glucose was determined prior to injection and then at 10, 30, 60, and 120 min after injection.

\section{Insulin sensitivity test}

The mice were given an i.p. injection (1.6U/kg body weight) of the insulin analog Actrapid (Novo Nordisk, Bagsværd, Denmark). Blood glucose was determined on blood samples from the tail, before injection and 15, 60, 120 and 180 min later using the Freestyle Mini System. The animals had free access to food before the insulin injection and were transferred to new cages without food during the measurements. 


\section{RESULTS}

\section{Generation and characterization of the novel NOX4 inhibitor GLX351322}

GLX351322 (ethyl 2-[[2-[4-(furan-2-carbonyl)piperazin-1-yl]acetyl]amino]-5,6dihydro-4H-cyclopenta [b]thiophene-3-carboxylate) (Fig. 1) was identified as a NOX inhibitor on the basis of a high throughput screening campaign involving a library of 40,000 compounds [30]. GLX351322 has previously been found to inhibit hydrogen peroxide production from tetracycline inducible NOX4 over-expressing cells with an IC50 of $5 \mu \mathrm{M}$, an ICmax of $85 \%$ and a Hill coefficient of 0.83 [30] (Table 1). After investigating GLX351322 for solubility, chemical stability, metabolic stability, protein binding and membrane passage (Table 1), the compound was tested for selectivity against NOX2 and found to be an order of magnitude less active against NOX2 (Table 1). In a $24 \mathrm{~h}$ health assessment in mice GLX351322 showed no signs of adverse effects after i.p. or p.o. administration (results not shown). When i.p. administration of the compound was extended to 11 days there were still no signs of adverse reactions (results not shown). According to data presented in Table 1, GLX351322 shows moderate chemical stability ( $>50 \%$ ) at physiological $\mathrm{pH}$ over a $24 \mathrm{~h}$ incubation at $37^{\circ} \mathrm{C}$. Plasma protein binding studies indicate very high binding ( $\mathrm{fu} \approx 0.03$ ) and good plasma stability. The results from metabolic stability studies suggest a moderate risk for high first pass metabolism. However, due to the high protein binding, which may limit the degree of tissue exposure, the risk is considered lowered. Caco-2 permeability studies indicate high permeability over biological membranes and a rapid uptake from the intestine. This was confirmed in the rat pharmacokinetic study. Determination of the pharmacokinetics 
of GLX351322 in rats after oral administration showed a rapid uptake into the blood stream and a t $1 / 2$ of $3 \mathrm{~h}$.

Antioxidant activity of GLX351322, as assessed by DPPH absorbance, was not observed (Fig. 2). As a positive control the redox active substance GLX481369 was used to demonstrate the titration curve of a redox active substance. This excludes the possibility that GLX351322 acts as a general antioxidant.

\section{Effects of GLX351322 on high-fat diet-induced glucose intolerance in mice}

The NOX-inhibitor GLX351322 was given to male C57BL/6 mice in the drinking water at $3.8 \mathrm{mg} / \mathrm{kg} /$ day, to determine whether high-fat diet-induced glucose intolerance is affected. We found that GLX351322 supplemented via the drinking water during the last two weeks of a nine-week long high-fat diet period did not affect the weight increase of the CD and HFD mice (Fig. 3A). The non-fasting blood glucose levels of high-fat diet mice were higher than control mice (Fig. 3B). The two-week GLX351322 treatment decreased the blood glucose of HFD mice, but not of CD mice (Fig. 3B).

The glucose tolerance of the different study groups was assessed by an i.v. glucose injection followed by determinations of blood glucose levels at $0,10,30,60$ and 120 min. We observed that GLX351322 did not affect glucose tolerance of mice fed a control diet (Fig. 4A). The glucose tolerance test of HFD mice was, however, markedly improved by GLX351322 at all time points (Fig. 4B). Furthermore, calculations of the area under the curve (AUC) showed that GLX351322 significantly improved glucose tolerance in high-fat diet mice (Fig. 4C). GLX351322 did not exert any effect on the AUC in CD mice. An insulin sensitivity test was performed and we observed that GLX351322 did not affect the insulin sensitivity of CD mice (Fig. 5A). HFD mice displayed a marked 
reduction in insulin sensitivity (Fig. 5B). The insulin sensitivity was not affected by the GLX351322 treatment (Fig. 5B).

\section{Acute effects of the NOX inhibitors GKT-136901 and GLX351322 on high glucose- and palmitate-stimulated human islet insulin release in vitro}

We next studied whether acute NOX4 inhibition affects islet insulin release in vitro. GKT136901 has previously been characterized as a NOX1/4 selective NOX inhibitor [28], and since NOX1 is not expressed in human islets (Fig. 6), it is likely that this inhibitor targets only NOX4. We observed that $10 \mu \mathrm{M}$ of GKT-136901 inhibited glucosestimulated insulin release from human islets during short-term (1-h) incubations (Fig. 7A). GLX351322 at a concentration of $2 \mu \mathrm{M}$ tended to decrease human islet insulin release at a high glucose concentration, but this did not reach statistical significance (Fig. 7B). Sodium palmitate is thought to stimulate insulin release by interaction with the FFA receptor FFAR1/GPR40 and via increased long-chain Acyl-CoA esters, and longterm palmitate effects are known to be deleterious for beta-cells [22,32,33]. We observed that palmitate-stimulated insulin release was decreased by GLX351322 at a concentration of $2 \mu \mathrm{M}$ (Fig. 7B), a concentration at which NOX4, but not NOX2, is partially inhibited. These findings add further support to a role for the NOX4 enzyme in both glucose- and palmitate-induced insulin release, and that islet NOX-generated ROS are involved in signaling events leading to calcium mobilization and insulin release, as previously suggested [17].

Long-term effects of GLX351322 on human islet ROS production and cell death in response to high glucose 
Human islets were cultured for $24 \mathrm{~h}$ in 5.6 or $28 \mathrm{mM}$ glucose to promote increased oxidative stress. The islets were then loaded with $\mathrm{H}_{2}$ DCFDA for 60 min at room temperature, followed by incubation for 60 min with or without $10 \mu \mathrm{M}$ GLX351322 or $10 \mu \mathrm{M}$ DPI at $37^{\circ} \mathrm{C}$. Islet cell DCF-fluorescence at basal and high glucose conditions was reduced in response to the non-specific NOX inhibitor DPI (Fig. 8). GLX351322 inhibited basal ROS production and partially also high glucose-induced DCF-fluorescence (Fig. 8), suggesting that other NOX enzymes besides NOX4 promote ROS production.

We next studied whether prolonged NOX4-generated ROS production in vitro participates in high glucose-induced beta-cell death. For this purpose, we cultured human islets for 3 days at different concentrations of the NOX inhibitor GLX351322. We observed that high glucose-induced islet cell death was efficiently counteracted by GLX351322 (Fig. 9).

\section{DISCUSSION}

We presently report that the novel NOX4 inhibitor GLX351322 counteracts high-fat dietinduced glucose intolerance in C57BL/6 mice, and that this occurs without any obvious improvement in peripheral insulin sensitivity. This finding may be explained by protection against ROS-induced beta-cell dysfunction by a fashion that differs from that in insulin sensitive peripheral tissues. In our study GLX351322 counteracted partially ROS production, high-glucose-induced islet cell death and the release of insulin in response to a high concentration of glucose in vitro, which fits well with the notion that oxidative stress is deleterious, and that beta-cell rest leads to long-term preservation of beta-cell function in vivo [35]. 
In our study NOX4 inhibition in vivo appears to target pancreatic islets and not peripheral insulin targets tissues. Previous studies have observed that increased oxidative stress promotes peripheral insulin resistance [11], and that systemic reduction of ROS/advanced glycation end products/NOX activity reduces insulin resistance [36-42]. The reason for the presently observed lack of effect of GLX351322 on peripheral insulin sensitivity is not known, but might relate to the isoform selectivity of GLX351322 as a NOX inhibitor or the level of ROS inhibition and/or expression of NOX enzymes in peripheral target tissues as compared to pancreatic islets. For example, islets may be more sensitive to increased glucose levels and ROS than peripheral target tissues due to differences in glucose transporter expression and antioxidative defense systems. According to our in vitro data, we observe that GLX351322 inhibits NOX4 8fold more effectively than NOX2. Thus, the lack of effect of GLX351322 on peripheral insulin sensitivity might also be explained by a low degree of NOX2 inhibition.

Recent RNA-seq results show that NOX4 mRNA contents are low in human islets, and even more so in EndoC-betaH1 beta-cells. Nevertheless, the NOX4 inhibitors GKT136901 and GLX351322 inhibited acute human islet insulin release in response to glucose and palmitate, and GLX351322 counteracted high-glucose induced islet cell death, which suggests that NOX4, either expressed in the beta-cells or in other islet cells located close to the beta-cells, promotes significant effects on islet function in vitro. Furthermore, it is possible that NOX4 levels could be considerably higher in vivo than in vitro, especially at diabetic conditions [43]. Indeed, it is known that NOX4 is highly expressed in endothelial cells [44], and that islets are highly vascularized in vivo [25], but that islet endothelial cells are lost during in vitro culture [45]. In line with this, it can be envisaged that a high production of ROS in the microenvironment surrounding the islet blood vessels, which is further enhanced by diabetic conditions, could promote 
negative effects on the beta-cells [46]. Thus, selective GLX351322-induced inhibition of NOX4 in vivo might mediate restoration of beta-cell function even though the beta-cell in vitro expression of NOX4 is low.

NOX4 differs from the other NOX enzymes in that it can generate both hydrogen peroxide and superoxide, and not only superoxide as most other NOX enzymes [47]. Moreover, NOX4 activity is mainly regulated at the mRNA expression level, and the protein localizes to other subcellular sites than NOX1/2/3/5. Interestingly, NOX4 gene expression appears to be controlled by miR-25 [43] and miR-146a [48], two microRNAs that are affected by aging and diabetes, respectively. The above-mentioned differences between NOX4 and NOX2 are compatible with the notion that NOX4 could play a specific role in islet dysfunction in diabetes.

In summary, our in vitro data suggest that NOX4 activity stimulates the release of insulin in response to a high glucose concentration. This is in accordance with previous studies supporting a stimulatory role of ROS in insulin secretion [16-19]. However, a recent study reported instead that NOX2-derived ROS antagonize glucose-induced insulin release [49]. Thus, results are conflicting as to whether NOX-derived ROS stimulate or inhibit insulin release, and it has been proposed that it is the intracellular source/location of the ROS produced that dictates the outcome [50]. As GLX351322 presently inhibited insulin release, it may be that NOX4 belongs to the ROS-generators that potentiate, rather than inhibit, the release of insulin. GLX351322 protected also against high glucose-induced islet cell death, aligning to the notion that human betacells, at least in part, die from hyperglycemia-induced oxidative stress [51]. Finally, GLX351322 counteracted beta-cell dysfunction in vivo, resulting in an improved glucose tolerance. Thus, prolonged NOX4-fueled ROS production and hypersecretion of insulin may be deleterious for the beta-cell, and it is possible that the use of NOX4 isoform- 
selective inhibitors might achieve targeted effects on the beta-cell. According to a recently proposed model insulin resistance and obesity in T2DM are not primary events, but instead secondary to beta-cell hypersecretion of insulin [52]. Factors that promote hypersecretion of insulin via increased ROS production were suggested to be not only free-fatty acids, but also environmental compounds such as artificial sweeteners, pollutants and hormones [52]. This model predicts that inhibition of ROS production/hypersecretion of insulin ameliorates not only beta-cell dysfunction and death, but also peripheral insulin resistance. Such a chain of events does not fully concur to the finding of this study, but it may be speculated that a longer time period than 2 weeks is necessary for a normalization of the insulin release to restore peripheral insulin sensitivity.

In conclusion, GLX351322 is a novel NOX4 selective inhibitor that ameliorates glucose intolerance in high-fat diet-treated mice. GLX351322 might achieve a better glucose homeostasis by not only reducing oxidative stress, but also by promoting beta-cell rest.

\section{DECLARATION OF INTEREST}

Patent: Wilcke M, Walum E, Wikström P. Thiophene-based compounds exhibiting nox4 inhibitory activity and use thereof in therapy. 2013 Patent application number PCT/EP2013/055218 


\section{REFERENCES}

[1] Weir GC, Bonner-Weir S. Islet $\beta$ cell mass in diabetes and how it relates to function, birth, and death. Ann N Y Acad Sci 2013;1281:92-105.

[2] Meneghini LF. Intensifying insulin therapy: what options are available to patients with type 2 diabetes? Am J Med 2013;126:S28-37.

[3] Robertson RP. Oxidative stress and impaired insulin secretion in type 2 diabetes. Curr Opin Pharmacol 2006;6:615-619.

[4] Newsholme P, Haber EP, Hirabara SM, Rebelato EL, Procopio J, Morgan D, OliveiraEmilio HC, Carpinelli AR, Curi R. Diabetes associated cell stress and dysfunction: role of mitochondrial and non-mitochondrial ROS production and activity. J Physiol 2007;583:9-24.

[5] Sakai K, Matsumoto K, Nishikawa T, Suefuji M, Nakamaru K, Hirashima Y, Kawashima J, Shirotani T, Ichinose K, Brownlee M, Araki E. Mitochondrial reactive oxygen species reduce insulin secretion by pancreatic beta-cells. Biochem Biophys Res Commun 2003;300:216-22.

[6] Evans JL, Goldfine ID, Maddux BA, Grodsky GM. Are oxidative stress-activated signaling pathways mediators of insulin resistance and beta-cell dysfunction? Diabetes 2003;52:1-8. 
[7] Wei Y, Sowers JR, Nistala R, Gong H, Uptergrove GM, Clark SE, Morris EM, Szary N, Manrique C, Stump CS. Angiotensin II-induced NADPH oxidase activation impairs insulin signaling in skeletal muscle cells. J Biol Chem 2006;281:35137-35146.

[8] Wu X, Williams KJ. NOX4 pathway as a source of selective insulin resistance and responsiveness. Arterioscler Thromb Vasc Biol 2012;32:1236-1245.

[9] Styskal J, Van Remmen H, Richardson A, Salmon AB. Oxidative stress and diabetes: what can we learn about insulin resistance from antioxidant mutant mouse models? Free Radic Biol Med 2012;52:46-58.

[10] Sedeek M, Callera G, Montezano A, Gutsol A, Heitz F, Szyndralewiez C, Page P, Kennedy CR, Burns KD, Touyz RM, Hébert RL. Critical role of NOX4-based NADPH oxidase in glucose-induced oxidative stress in the kidney: implications in type 2 diabetic nephropathy. Am J Physiol Renal Physiol 2010;299:F1348-1358.

[11] Matsuzawa-Nagata N, Takamura T, Ando H, Nakamura S, Kurita S, Misu H, Ota T, Yokoyama M, Honda M, Miyamoto K, Kaneko S. Increased oxidative stress precedes the onset of high-fat diet-induced insulin resistance and obesity. Metabolism 2008;57:10711077.

[12] Guichard C, Moreau R, Pessayre D, Epperson TK, Krause KH. NOX family NADPH oxidases in liver and in pancreatic islets: a role in the metabolic syndrome and diabetes? Biochem Soc Trans 2008;236:920-929. 
[13] Oliveira HR, Verlengia R, Carvalho CR, Britto LR, Curi R, Carpinelli AR. Pancreatic beta-cells express phagocyte-like NAD(P)H oxidase. Diabetes 2003;52:1457-1463.

[14] Uchizono Y, Takeya R, Iwase M, Sasaki N, Oku M, Imoto H, Iida M, Sumimoto H. Expression of isoforms of NADPH oxidase components in rat pancreatic islets. Life Sci 2006;80:133-139.

[15] Rebelato E, Mares-Guia TR, Graciano MF, Labriola L, Britto LR, Garay-Malpartida HM, Curi R, Sogayar MC, Carpinelli AR. Expression of NADPH oxidase in human pancreatic islets. Life Sci 2012;91:244-249.

[16] Morgan D, Rebelato E, Abdulkader F, Graciano MF, Oliveira-Emilio HR, Hirata AE, Rocha MS, Bordin S, Curi R, Carpinelli AR. Association of NAD(P)H oxidase with glucoseinduced insulin secretion by pancreatic beta-cells. Endocrinology 2009;150:2197-2201.

[17] Imoto H, Sasaki N, Iwase M, Nakamura U, Oku M, Sonoki K, Uchizono Y, Iida M. Impaired insulin secretion by diphenyleneiodium associated with perturbation of cytosolic Ca2+ dynamics in pancreatic beta-cells. Endocrinology 2008;149:5391-5400.

[18] Syed I, Kyathanahalli CN, Kowluru A. Phagocyte-like NADPH oxidase generates ROS in INS 832/13 cells and rat islets: role of protein prenylation. Am J Physiol Regul Integr Comp Physiol 2011;300:R756-762.

[19] Syed I, Kyathanahalli CN, Jayaram B, Govind S, Rhodes CJ, Kowluru RA, Kowluru A. Increased phagocyte-like NADPH oxidase and ROS generation in type 2 diabetic ZDF rat 
and human islets: role of Rac1-JNK1/2 signaling pathway in mitochondrial dysregulation in the diabetic islet. Diabetes 20122;60:2843-2852.

[20] Syed I, Jayaram B, Subasinghe W, Kowluru A. Tiam1/Rac1 signaling pathway mediates palmitate-induced, ceramide-sensitive generation of superoxides and lipid peroxides and the loss of mitochondrial membrane potential in pancreatic beta-cells. Biochem Pharmacol 2010;80:874-883.

[21] Zhou YP, Grill VE. Long-term exposure of rat pancreatic islets to fatty acids inhibits glucose-induced insulin secretion and biosynthesis through a glucose fatty acid cycle. J Clin Invest 1994;93:870-876.

[22] Graciano MF, Valle MM, Curi R, Carpinelli AR. Evidence for the involvement of GPR40 and NADPH oxidase in palmitic acid-induced superoxide production and insulin secretion. Islets 2013;5:139-148.

[23] Patel H, Chen J, Das KC, Kavdia M. Hyperglycemia induces differential change in oxidative stress at gene expression and functional levels in HUVEC and HMVEC. Cardiovasc Diabetol 2013;12:142.

[24] Hecker L, Logsdon NJ, Kurundkar D, Kurundkar A, Bernard K, Hock T, Meldrum E, Sanders YY, Thannickal, VJ. Reversal of persistent fibrosis in aging by targeting NOX4Nrf2 redox imbalance. Sci Transl Med 2014;6:231ra47 
[25] Lau J, Carlsson P0. Low revascularization of human islets when experimentally transplanted into the liver. Transplantation 2009;287:322-325.

[26] Weaver JR, Holman TR, Imai Y, Jadhav A, Kenyon V, Maloney DJ, Nadler JL, Rai G, Simeonov A, Taylor-Fishwick DA. Integration of pro-inflammatory cytokines, 12lipoxygenase and NOX-1 in pancreatic islet beta cell dysfunction. Mol Cell Endocrinol 2012;358:88-95.

[27] Altenhöfer S, Radermacher KA, Kleikers PW, Wingler K, Schmidt HH. Evolution of NADPH Oxidase Inhibitors: Selectivity and Mechanisms for Target Engagement. Antioxid. Redox Signal 2014;doi:10.1089/ars.2013.5814.

[28] Sedeek M, Callera G, Montezano A, Gutsol A, Heitz F, Szyndralewiez C, Page P, Kennedy CR, Burns KD, Touyz RM, Hébert RL. Critical role of NOX4-based NADPH oxidase in glucose-induced oxidative stress in the kidney: implications in type 2 diabetic nephropathy. Am J Physiol Renal Physiol 2010;299:F1348-1358.

[29] Xiong Q, Kadota S, Tani T, Namba T. Antioxidative effects of phenylethanoids from Cistanche deserticola. Biol Pharm Bull 1996;19:1580-1585.

[30] Wilcke M, Walum E, Wikström, P. Thiophene-based compounds exhibiting nox4 inhibitory activity and use thereof in therapy. 2013 Patent application number PCT/EP2013/055218. 
[31] Kreher CR, Dittrich MT, Guerkov R, Boehm BO, Tary-Lehmann M. CD4+ and CD8+ cells in cryopreserved human PBMC maintain full functionality in cytokine ELISPOT assays. J Immunol Methods 2003;278:79-93.

[32] Hubatsch I, Ragnarsson EGE, Artursson P. Determination of drug permeability and prediction of drug absorption in Caco-2 monolayers. Nature Protocols 2007;2:21112119.

[33] Kristinsson H, Smith DM, Bergsten P, Sargsyan E. FFAR1 is involved in both the acute and chronic effects of palmitate on insulin secretion. Endocrinology $2013 ; 154: 4078-4088$.

[34] Prentki M, Vischer S, Glennon MC, Regazzi R, Deeney JT, Corkey BE. Malonyl-CoA and long chain acyl-CoA esters as metabolic coupling factors in nutrient-induced insulin secretion. J Biol Chem 1992;267:5802-5810.

135] Brown RJ, Rother KI. Effects of beta-cell rest on beta-cell function: a review of clinical and preclinical data. Pediatr Diabetes 2008;9:14-22.

[36] Ikemura M, Nishikawa M, Hyoudou K, Kobayashi Y, Yamashita F, Hashida M. Improvement of insulin resistance by removal of systemic hydrogen peroxide by PEGylated catalase in obese mice. Mol Pharm 2010;7:2069-2076.

[37] Raddatz K, Turner N, Frangioudakis G, Liao BM, Pedersen DJ, Cantley J, Wilks D, Preston E, Hegarty BD, Leitges M, Raftery MJ, Biden TJ, Schmitz-Peiffer C. Time- 
dependent effects of Prkce deletion on glucose homeostasis and hepatic lipid metabolism on dietary lipid oversupply in mice. Diabetologia 2011;54:1447-1456.

[38] Hagiwara S, Gohda T, Tanimoto M, Ito T, Murakoshi M, Ohara I, Yamazaki T, Matsumoto M, Horikoshi S, Funabiki K, Tomino Y. Effects of pyridoxamine (K-163) on glucose intolerance and obesity in high-fat diet C57BL/6J mice. Metabolism 2009;58:934-945.

[39] Zhang ZF, Lu J, Zheng YL, Wu DM, Hu B, Shan Q, Cheng W, Li MQ, Sun YY. Purple sweet potato color attenuates hepatic insulin resistance via blocking oxidative stress and endoplasmic reticulum stress in high-fat-diet-treated mice. J Nutr Biochem $2013 ; 24: 1008-1018$

[40] Kendig EL, Schneider SN, Clegg DJ, Genter MB, Shertzer HG. Over-the-counter analgesics normalize blood glucose and body composition in mice fed a high fat diet. Biochem Pharmacol 2008;2076:216-224.

[41] Espinosa A, Campos C, Díaz-Vegas A, Galgani JE, Juretic N, Osorio-Fuentealba C, Bucarey JL, Tapia G, Valenzuela R, Contreras-Ferrat A, Llanos P, Jaimovich E. Insulindependent $\mathrm{H} 2 \mathrm{O} 2$ production is higher in muscle fibers of mice fed with a high-fat diet. Int J Mol Sci 2013;14:15740-15754.

[42] Li Y, Mouche S, Sajic T, Veyrat-Durebex C, Supale R, Pierroz D, Ferrari S, Negro F, Hasler U, Feraille E, Moll S, Meda P, Deffert C, Montet X, Krause KH, Szanto I. Deficiency 
in the NADPH oxidase 4 predisposes towards diet-induced obesity. Int J Obes (Lond) 2013;36:1503-1513.

[43] Fu Y, Zhang Y, Wang Z, Wang L, Wei X, Zhang B, Wen Z, Fang H, Pang Q, Yi F. Regulation of NADPH oxidase activity is associated with miRNA-25-mediated NOX4 expression in experimental diabetic nephropathy. Am J Nephrol 2010;32:581-589.

[44] Takac I, Schröder K, Brandes RP. The NOX family of NADPH oxidases: friend or foe of the vascular system? Curr Hypertens Rep 2012;14:70-78.

[45] Parr EL, Bowen KM, Lafferty KJ. Cellular changes in cultured mouse thyroid glands and islets of Langerhans. Transplantation 1980;30:135-141.

[46] Lacraz G, Giroix MH, Kassis N, Coulaud J, Galinier A, Noll C, Cornut M, Schmidlin F, Paul JL, Janel N, Irminger JC, Kergoat M, Portha B, Donath MY, Ehses, JA. Homo-Delarche F. Islet endothelial activation and oxidative stress gene expression is reduced by IL-1Ra treatment in the type 2 diabetic GK rat. PLoS One 2009;24:e6963.

[47] Takac I, Schröder K, Zhang L, Lardy B, Anilkumar N, Lambeth JD, Shah AM, Morel F, Brandes RP. The E-loop is involved in hydrogen peroxide formation by the NADPH oxidase NOX4. J Biol Chem 2011;286:13304-13313

[48] Vasa-Nicotera $M$, Chen $H$, Tucci P, Yang AL, Saintigny G, Menghini R, Mahè C, Agostini M, Knight RA, Melino G, Federici M. miR-146a is modulated in human endothelial cell with aging. Atherosclerosis 2011;217:326-330. 
[49] Li N, Li B, Brun T, Deffert-Delbouille C, Mahiout Z, Daali Y, Ma XJ, Krause KH, Maechler P. NADPH oxidase NOX2 defines a new antagonistic role for reactive oxygen species and cAMP/PKA in the regulation of insulin secretion. Diabetes 2012;61:28422850.

[50] Mailloux RJ, Fu A, Robson-Doucette C, Allister EM, Wheeler MB, Screaton R, Harper ME. Glutathionylation state of uncoupling protein-2 and the control of glucosestimulated insulin secretion. J Biol Chem 2012;287:39673-39685

[51] Robertson R, Zhou H, Zhang T, Harmon JS. Chronic oxidative stress as a mechanism for glucose toxicity of the beta cell in type 2 diabetes. Cell Biochem Biophys 2007;48:139-146.

[52] Corkey BE. Diabetes: have we got it all wrong? Insulin hypersecretion and food additives: cause of obesity and diabetes? Diabetes Care 2012;35:2432-2437.

[53] Fred RG, Kappe C, Ameur A, Cen J. Bergsten P, Ravassard P, Scharfmann R, Welsh N Role of the AMP kinase in cytokine-induced human EndoC- $\beta \mathrm{H} 1$ cell death. Mol Cell Endo, conditionally accepted for publication. 
Table 1

\section{Characteristics of GLX351322}

\begin{tabular}{|l|l|}
\hline $\mathrm{IC}_{50}, \mathrm{NOX} 4$ inhibition in TRex 293 cells & $5 \mu \mathrm{M}$ \\
\hline $\mathrm{IC}_{\text {max }}$, NOX4 inhibition & $85 \%$ \\
\hline Hill coefficient, NOX4 inhibition & 0.83 \\
\hline $\mathrm{IC}_{50}, \mathrm{NOX} 2$ inhibition in hPBMC cells & $40 \mu \mathrm{M}$ \\
\hline Solubility in KP, FASSIF blank and FASSIF & $2.7 \mu \mathrm{M}, 1.4$ and 18,9 \\
\hline Chemical stability, parent compound remaining & $64 \%$ and $55 \%$ \\
\hline after 2 and 24 h & \\
\hline Metabolic stability, $\mathrm{t}_{1 / 2}$ human liver & $25 \mathrm{~min}$ \\
\hline microsomes & \\
\hline Plasma protein binding, \% free fraction & 0.03 \\
\hline Permeability, Caco-2 cells, Papp a-b & $2.9 \mathrm{~h}$ and $1620 \mathrm{nMxh}$ \\
\hline Oral pharmacokinetics, rat, $\mathrm{t}_{1 / 2}$ and AUC & \\
\hline
\end{tabular}




\section{LEGENDS TO THE FIGURES}

Figure 1. Structure of GLX351322.

Figure 2. GLX351322 does not affect DPPH absorbance. DPPH was incubated with decreasing concentrations (200-0.003 $\mu \mathrm{M})$ of GLX351322 or GLX481369 (positive control) and absorbance at $518 \mathrm{~nm}$ was measured after $60 \mathrm{~min}$.

Figure 3. GLX351322 ameliorates HFD-induced hyperglycemia. (A)_Weight curve of C57BL/6 mice given a normal diet or a high-fat diet from 5 to 14 weeks of age. After 7 weeks of control (CD, 20 mice) and high-fat diet (HFD, 20 mice) (age 12 weeks) mice were divided into four groups; CD or HFD with or without GLX351322 (3.8 mg/kg/day) and followed for another 2 weeks. GLX351322 supplementation in the drinking water did not affect the weight increase during the 2-week treatment period. (B) Non-fasting blood glucose of CD or HFD mice treated for 2 weeks with GLX351322. Blood glucose was analyzed after 5 weeks ( 10 weeks of age) and after 7 weeks (12 weeks of age) after start of HFD. After the 7 weeks of HFD mice were randomly divided into four groups; CD or HFD with or without GLX351322 (3.8 mg/kg/day) and followed for another 2 weeks.

* denotes p<0.05 vs. HFD mice without GLX351322 treatment using Student paired ttest.

Figure 4. Glucose tolerance test of CD and HFD mice treated with GLX351322. After two weeks of GLX351322 treatment CD (A) and HFD (B) mice were fasted for 8 hours and injected intraperitoneally with glucose $(25 \mathrm{~g} / \mathrm{kg})$. Blood glucose levels were analyzed at the time points given in the Figure. Results are means \pm SEM for 10 mice in each group. * 
denotes p<0.05 vs. HFD mice without GLX351322 treatment using Student independent t-test. (C) Data from Figures 3A and 3B were recalculated to Area Under Coordinates (AUC, C(I)). * denotes $\mathrm{p}<0.05$ vs. HFD mice without GLX351322 treatment using Student t-test.

Figure 5. Insulin sensitivity test of CD (A) and HFD (B) mice treated for 2 weeks with GLX351322. Insulin (1.6 U/kg Actrapid) was injected intraperitoneally and blood glucose was analyzed at the time points given in the Figure. Results are means \pm SEM for 10 mice in each group.

Figure 6. Levels of mRNA coding for different NOX enzymes in human islets and EndoCbetaH1 cells. Expression levels at basal conditions of different NOXes as assessed by RNA-seq. Results are expressed as reads per kilobase per million (RPKM) and are normalized for exon length Results are means \pm SEM for 3 independent observations and are modified from [53]. * denotes $\mathrm{p}<0.05$ using Student's t-test.

Figure 7. Effects of GKT-136901 (A) and GLX351322 (B) on human islet glucose- and palmitate-stimulated insulin release. (A) Human islets were incubated $60 \mathrm{~min}$ at $1.7 \mathrm{mM}$ glucose (Control LG), 1.7 mM glucose plus $10 \mu \mathrm{M}$ GKT-136901 (LG GKT), 17 mM glucose (Control HG) and 17 mM glucose plus GKT-136901 (HG GKT). (B) Human islets were incubated for 60 min with (Palmitate) or without (Control) $0.5 \mathrm{mM}$ sodium palmitate. All groups were incubated at $17 \mathrm{mM}$ glucose. GLX351322 was added at a concentration of $2 \mu \mathrm{M}$. Results are means \pm SEM for 7-8 observations. * denotes $\mathrm{p}<0.05$ vs. corresponding control using Student paired t-test. 
Figure 8. GLX351322 and DPI reduce human islet ROS production. Islets were precultured for $24 \mathrm{~h}$ in 5.6 or $28 \mathrm{mM}$ glucose. After loading of the fluorescent dye $\mathrm{H}_{2}$ DCFDA $(10 \mu \mathrm{M})$ at room temperature, the islets were returned to culture conditions for a final 60 min incubation with or without GLX351322 (10 $\mu \mathrm{M})$ and DPI $(10 \mu \mathrm{M})$. Hoechst stain (10 $\mu \mathrm{g} / \mathrm{ml}$ ) was added during the final $20 \mathrm{~min}$ of the incubation. Islets were then analyzed by confocal microscopy. Results are means \pm SEM for three independent experiments in which $2-4$ islets per group were analyzed. * denotes $\mathrm{p}<0.05$ using Student's unpaired t-test.

Figure 9. Effects of GLX351322 (2 and $10 \mu \mathrm{M})$ on human islet cell death in response to high glucose. After a 3-day culture period in the presence of $20 \mathrm{mM}$ glucose (high glucose) islets were labeled with propidium iodide and Hoechst and then analyzed in a Kodak 4000MM Image station for blue and red fluorescence. The ratio red/blue fluorescence was calculated and normalized to the control. Results are means \pm SEM for 5 independent observations * denotes $\mathrm{p}<0.05$ vs. corresponding control using Student paired t-test. 


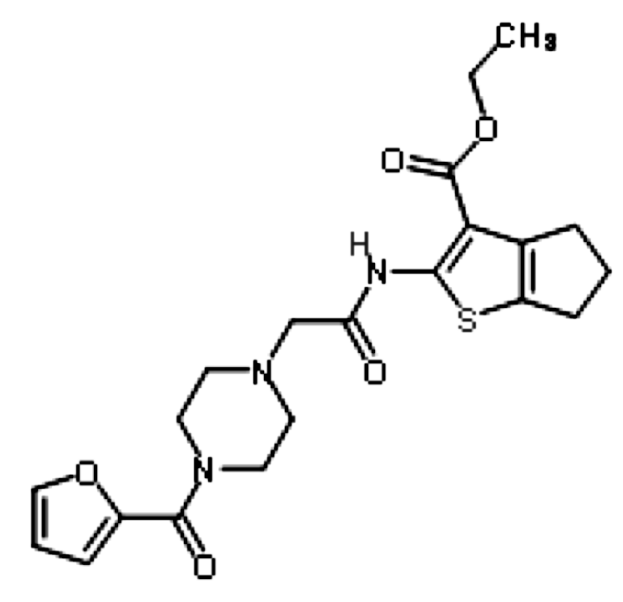




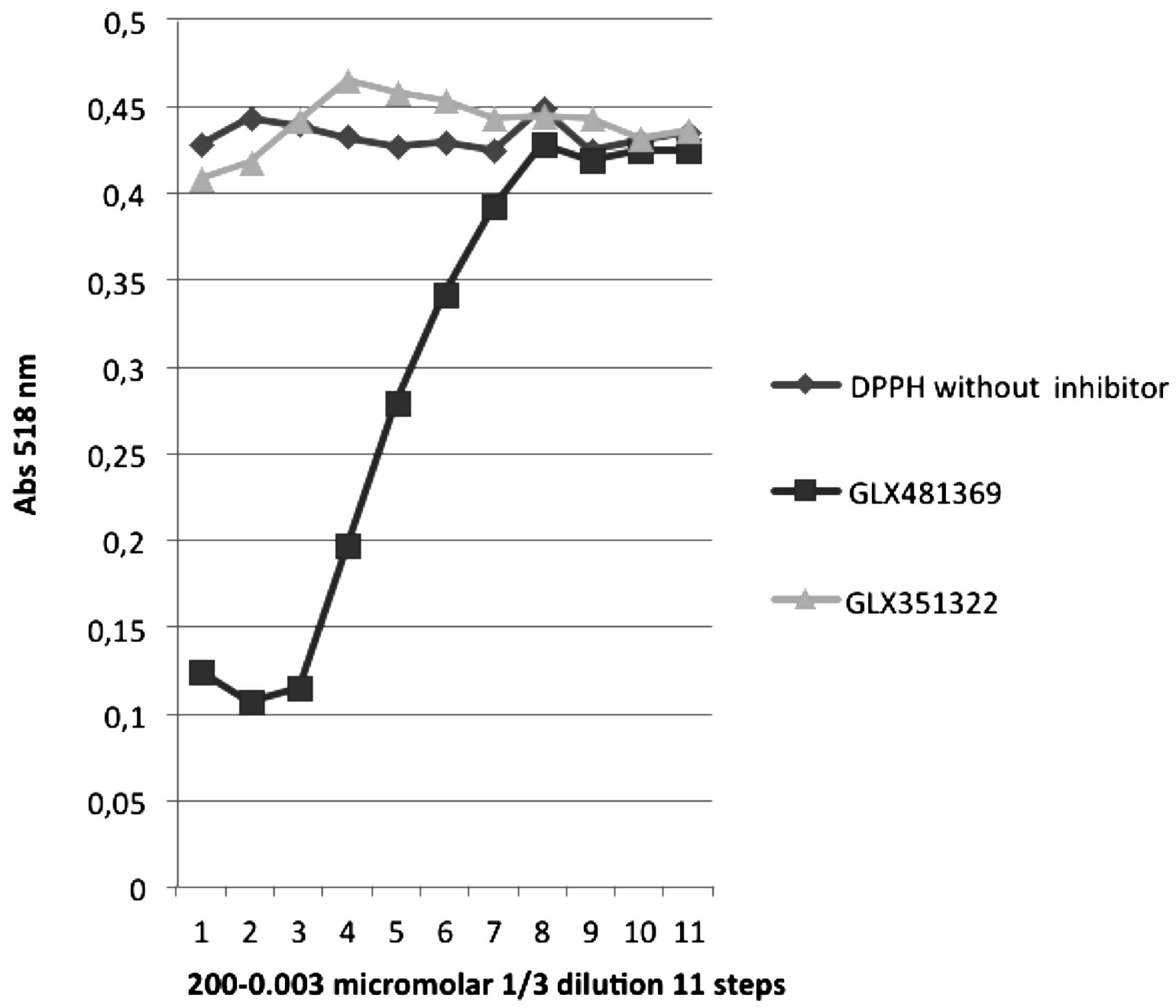



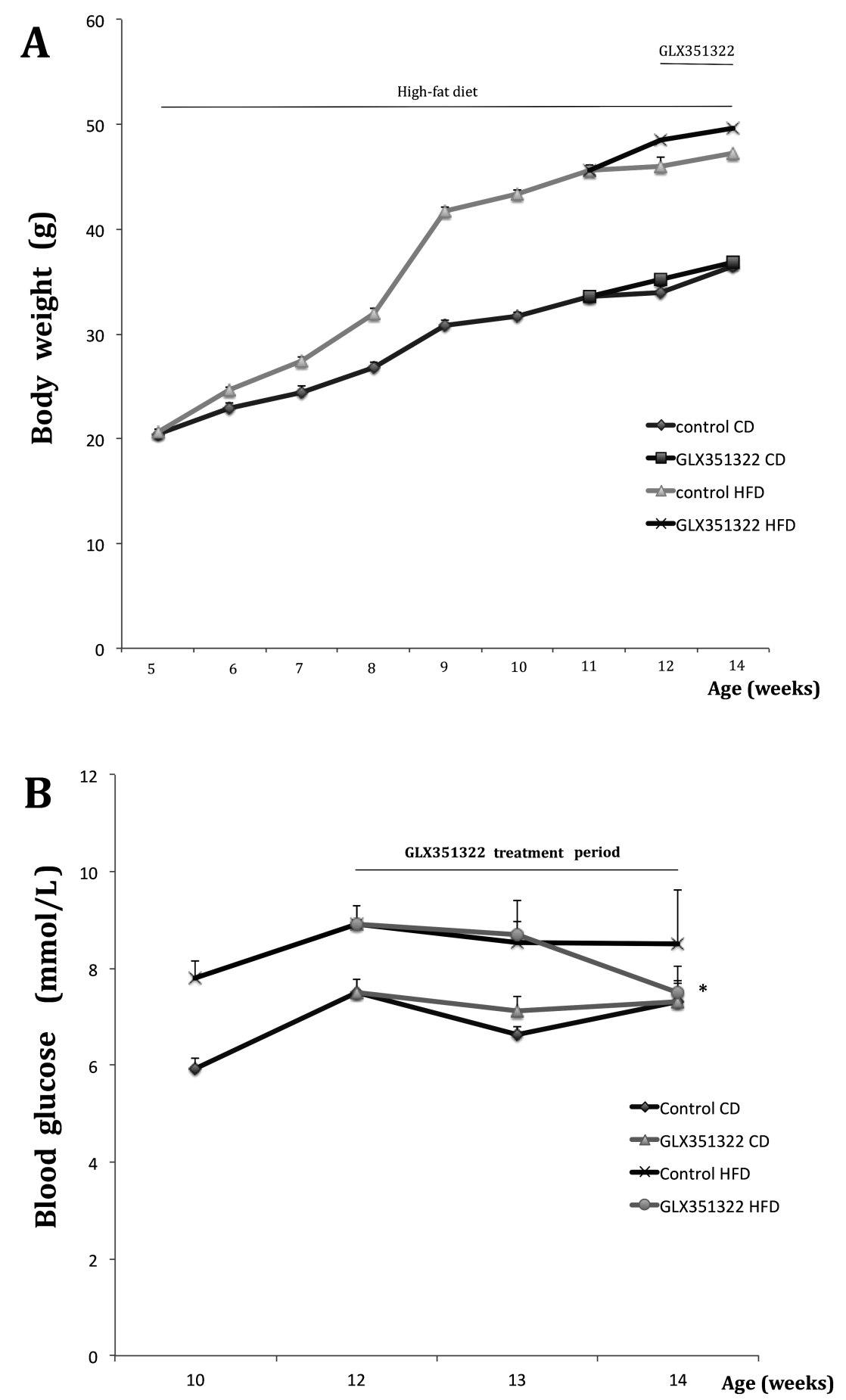

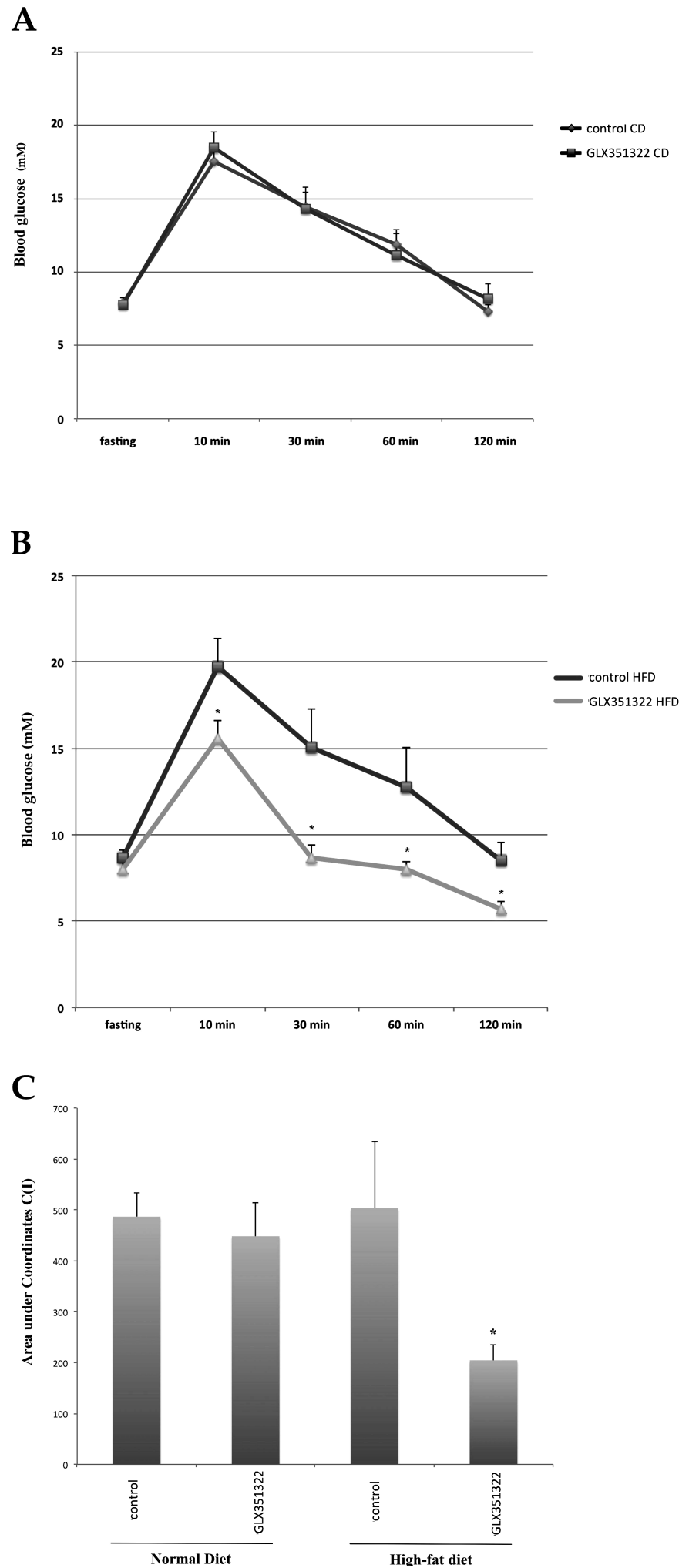

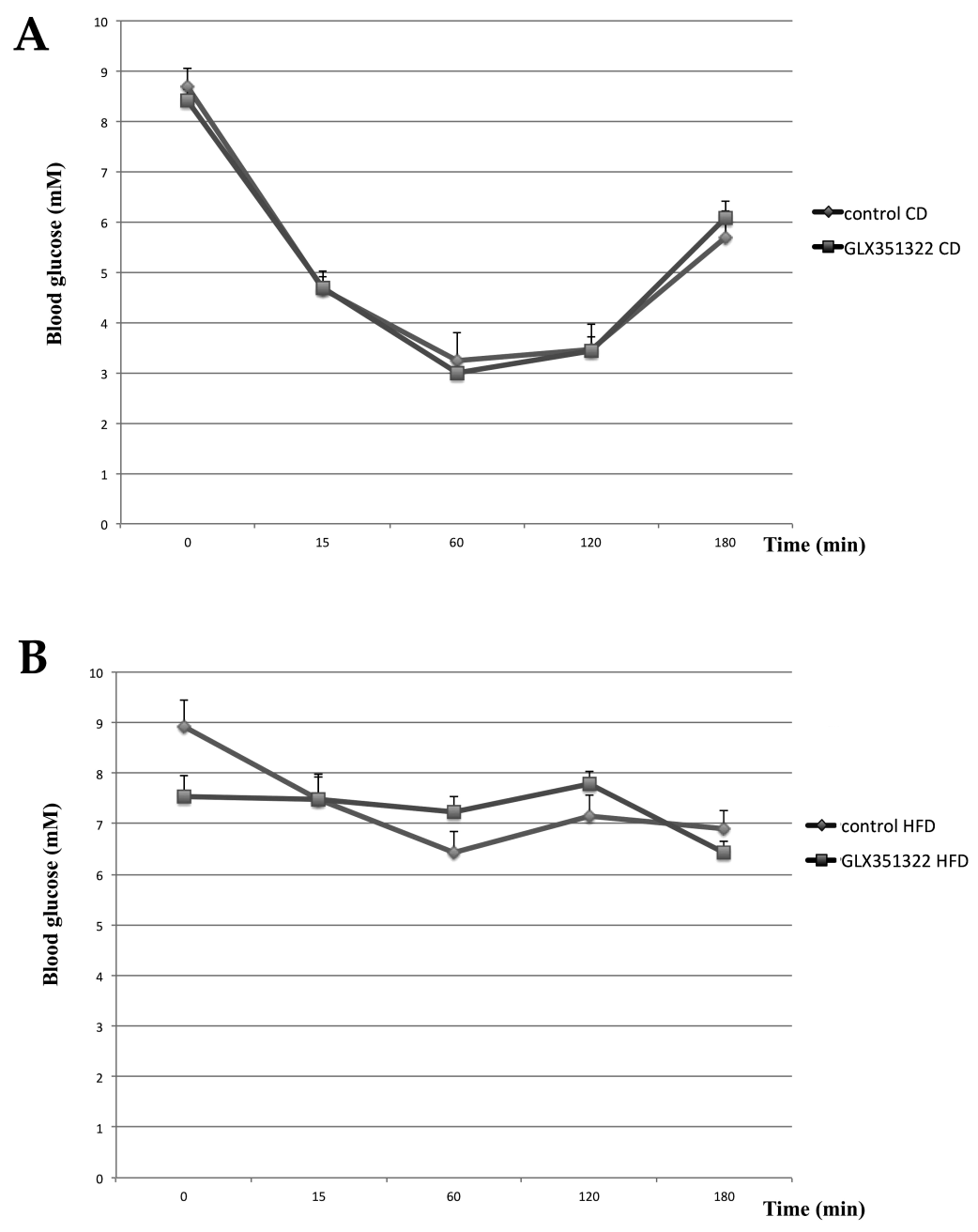


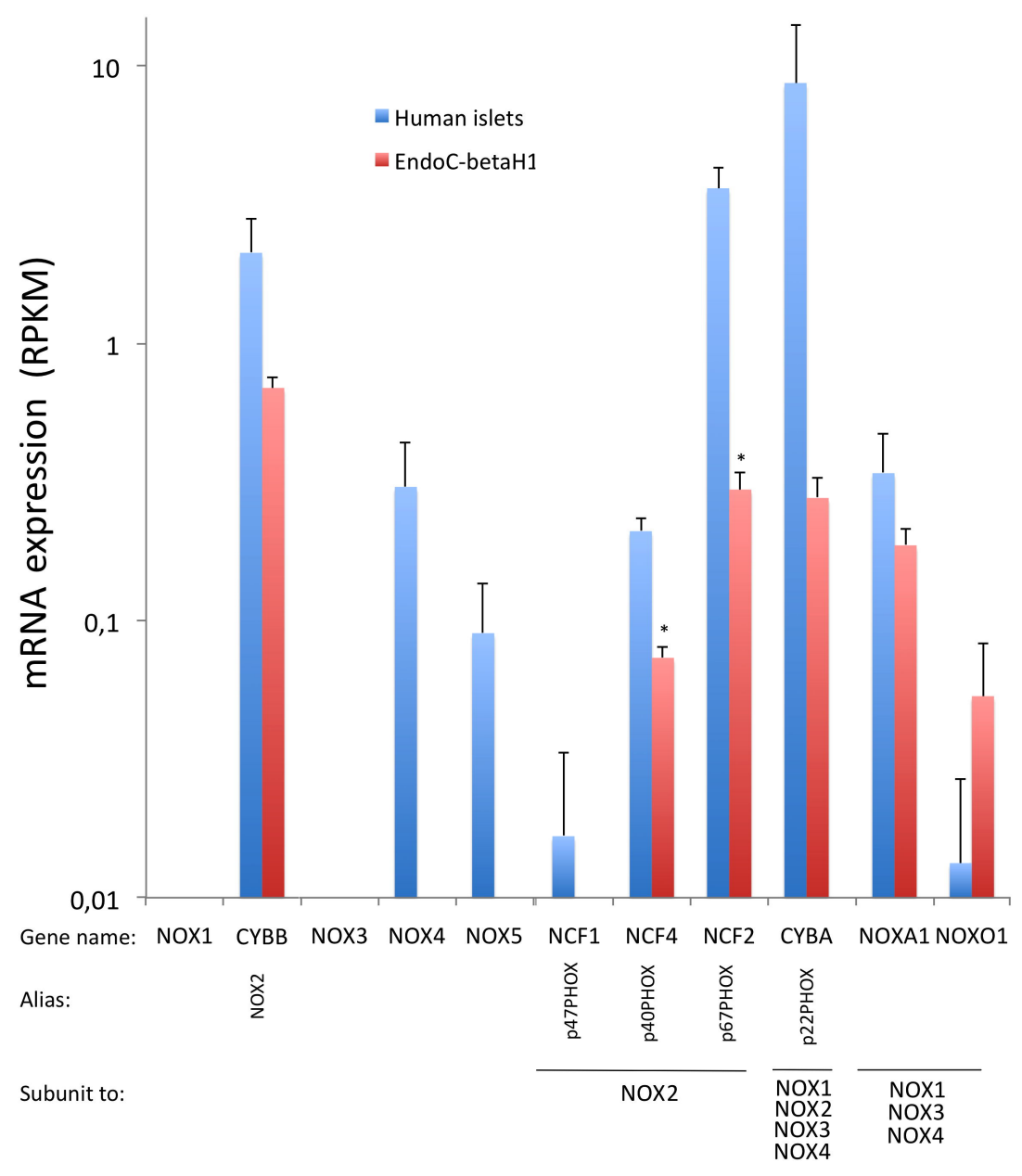


A

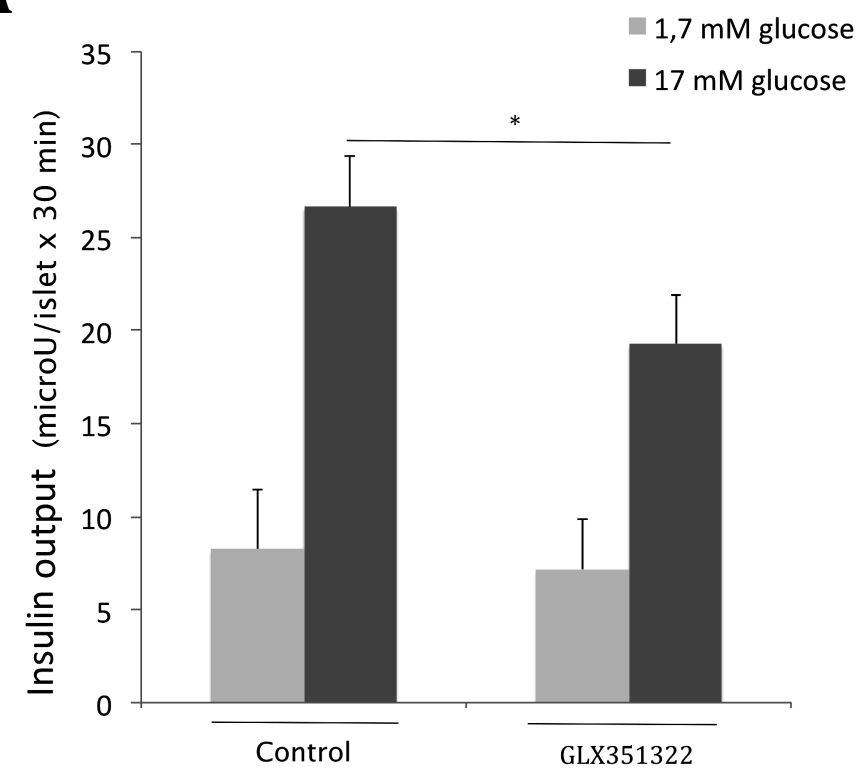

B

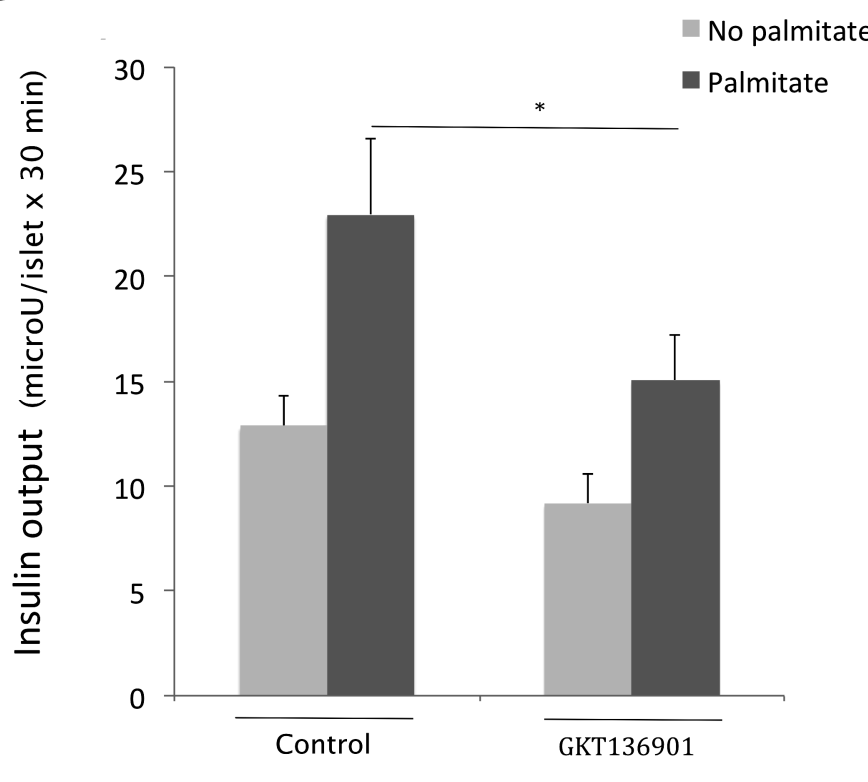



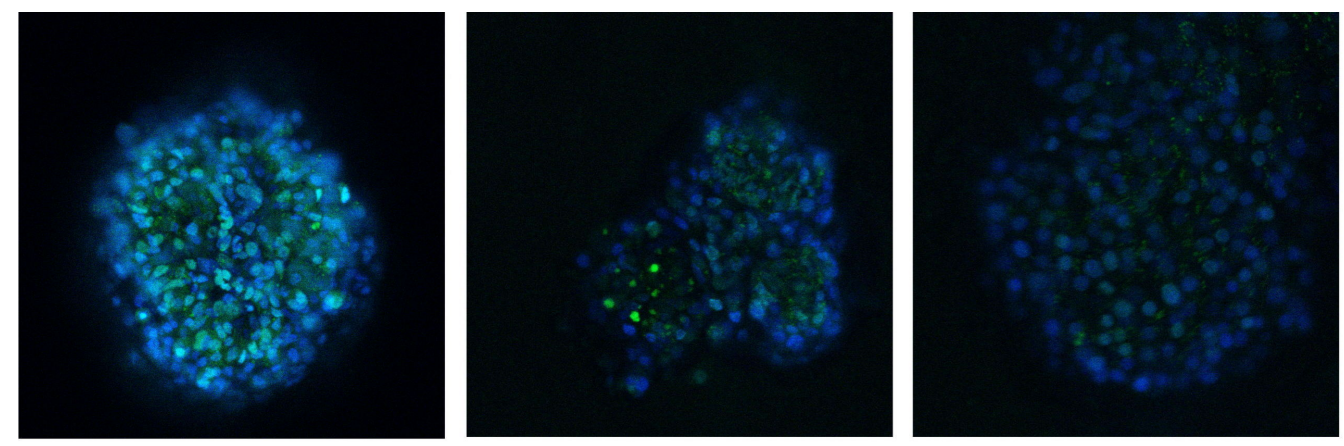

$5.6 \mathrm{mM}$

Glucose
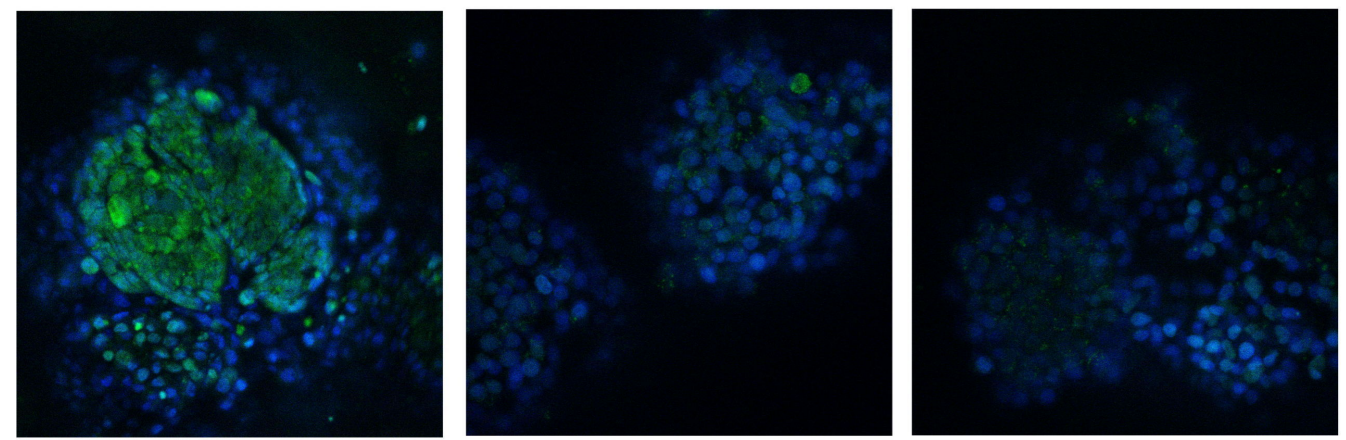

$28 \mathrm{mM}$

Glucose

Control

GLX351322

DPI

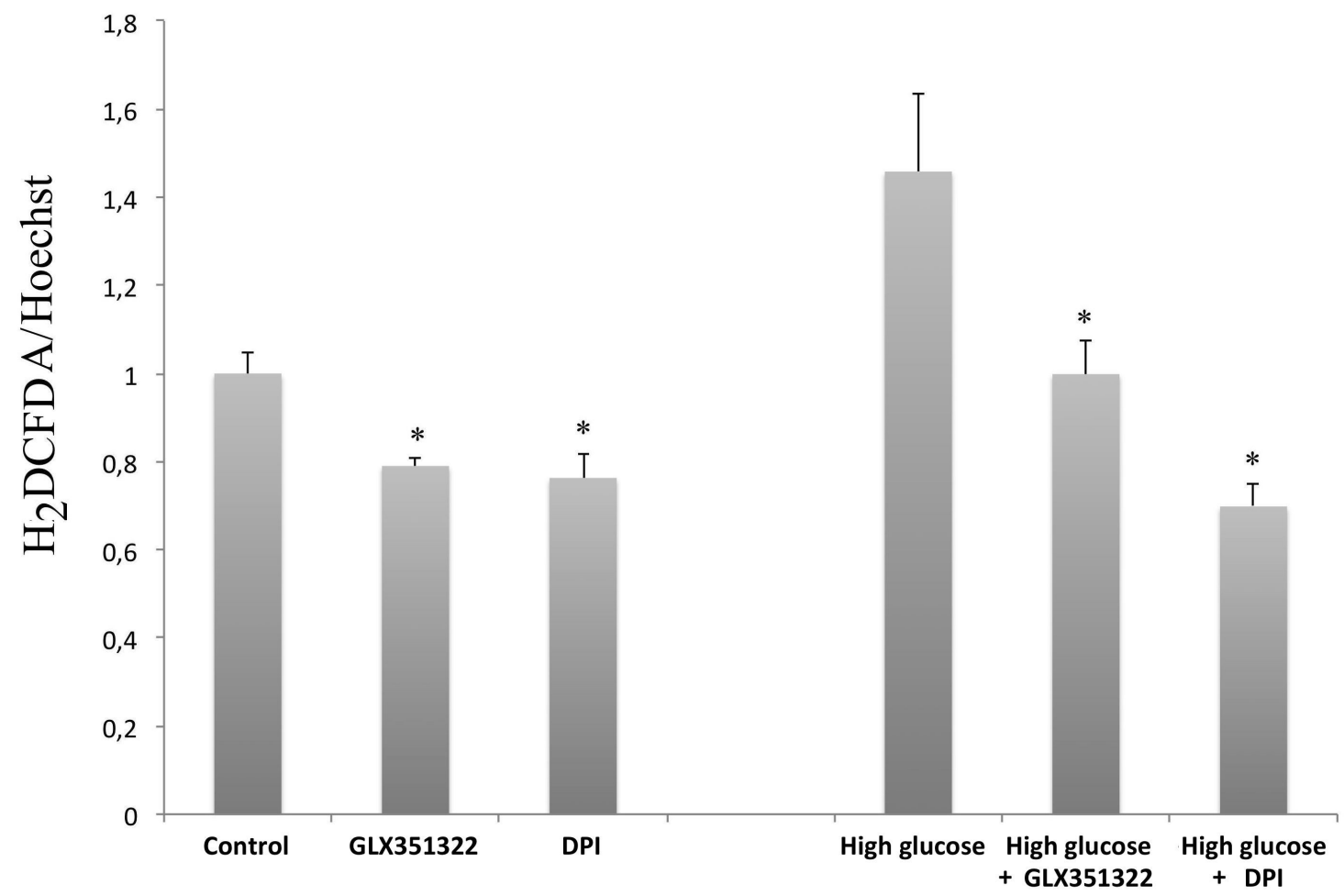




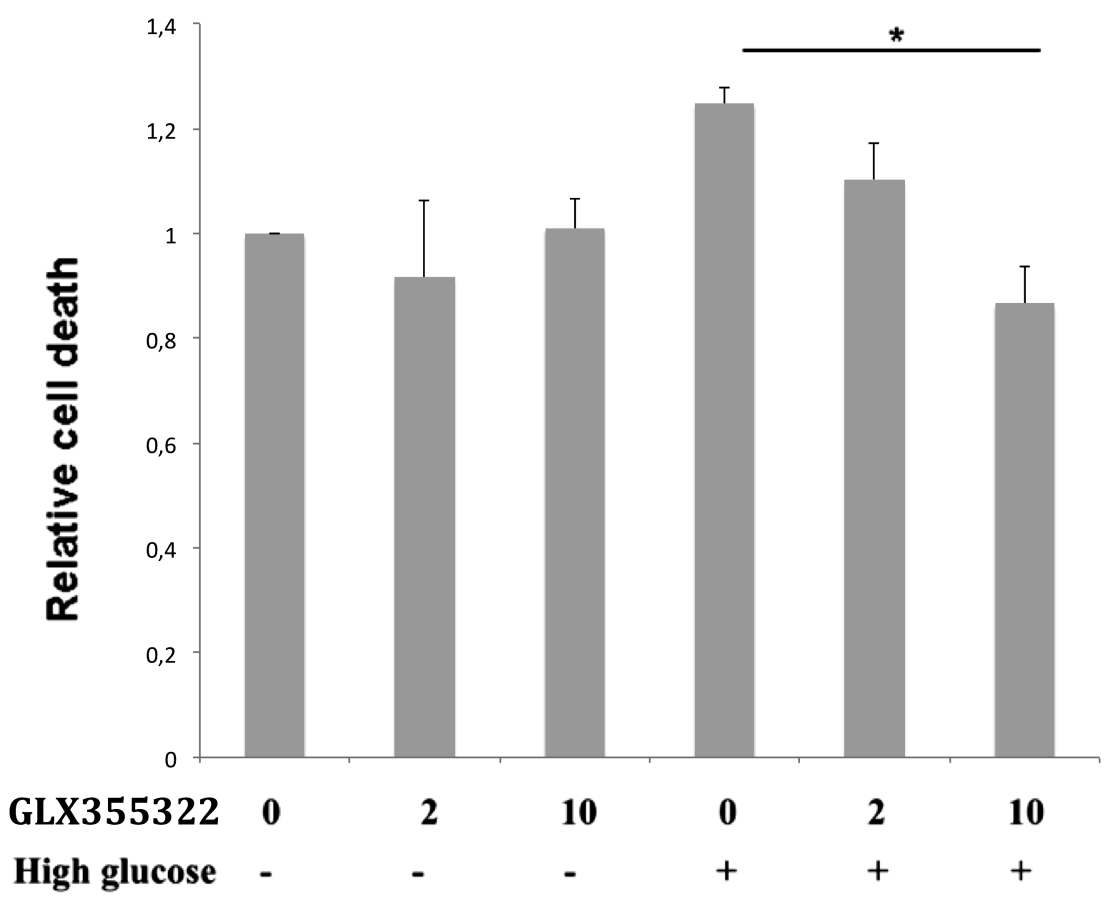

